\title{
Medstudentundervisning og -læring: et emosjonelt perspektiv
}

Beate Ytreberg

I kapittelet tar jeg utgangspunkt i en læringsaktivitet fra bachelorutdanningen i fysioterapi der studenter fra samme kull underviser hverandre, med egne praksiserfaringer som grunnlag. Lærerne strukturerer læringsaktiviteten på forhånd, gir støtte underveis, bidrar med tilbakemeldinger og er en samlende faktor for hele prosessen. Medstudentundervisning og -læring aktualiserer emosjonenes betydning i situert læring, aktiv læring og dybdelæring. Kapittelet avsluttes med å undersøke lærerrollen og studentrollen når studenter får ansvar for undervisning. Studentenes stemmer kommer tydelig fram, representert ved sitater fra deltakere fra fokusgrupper i et forskningsprosjekt.

\section{Innledning}

Kapittelet bygger på resultater fra et kvalitativt fokusgruppebasert forskningsprosjekt om medstudentundervisning og -læring. Målet med prosjektet var å få innsikt i fysioterapeutstudenters erfaringer fra en medstudentstyrt læringsaktivitet. Datainnsamlingen ble gjennomført i 2012 og $2013,{ }^{1}$ og prosjektet ble fullført i 2014 . I en artikkel fra prosjektet finnes utfyllende teori om medstudentlæring, en grundigere beskrivelse av selve læringsaktiviteten og av metode. Studiens konklusjon er at medstudentundervisning og -læring aktiverer emosjoner, og at studentene

Videre brukes «Student 2012» og «Student 2013» som referanser i studentsitater. 
løfter fram emosjoner som viktig for egen læring (Ytreberg \& Aars, 2015). I dette kapittelet tar jeg utgangspunkt i artikkelens konklusjoner og utdyper og utvider forståelsen av emosjonenes betydning for medstudentlæring. Først beskrives læringsaktiviteten helt kort (medstudentundervisning og -læring $\left(\mathrm{MUL}^{2}\right)$. Deretter diskuteres emosjonenes ${ }^{3}$ betydning for medstudentundervisning og -læring, med særlig fokus på situert læring, aktiv læring og dybdelæring. Til slutt reflekterer jeg over hvordan studentrollen og lærerrollen endres når studentene selv får hovedansvar for å undervise hverandre. Teksten er illustrert og underbygges av studentens utsagn. ${ }^{4}$

\section{Medstudentundervisning og -læring (MUL) - et eksempel fra fysioterapeututdanningen}

I medstudentundervisning og -læring (MUL) brukes oftest seniorstudenter som lærere for studenter som befinner seg i tidligere faser av samme studieløp (Topping \& Ehly, 2001). MUL-aktiviteten som beskrives her, skjer mellom fysioterapeutstudenter på samme kull. De samme studentene erfarer derfor både rollen som lærer (heretter kalt studentlærer), og rollen som student. Her beskriver jeg kort planlegging og gjennomføring av slik medstudentundervisning og -læring (MUL) i fysioterapeutstudiets tredje semester.

\section{Undervisningsoppleggets plassering i studieløpet}

På bachelorutdanningen i fysioterapi ved UiT Norges arktiske universitet gjennomføres flere MUL-opplegg. Ett av disse er plassert i slutten av tredje semester ${ }^{5}$ og har fokus på utvikling av dybdekunnskap med MUL som pedagogisk metode. I løpet av fire-fem dager forbereder studentene undervisning

\footnotetext{
2 Oversatt av forfatter fra det engelske begrepet peer teaching and learning og forkortet til MUL av praktiske hensyn.

3 Damasio skiller mellom emosjoner og følelser: Emosjoner er de observerbare og målbare endringene i kroppen, og følelser er den subjektive opplevelsen (Damasio, 2002). Her brukes begrepene synonymt og omfatter både det observerbare og det subjektivt opplevde.

4 Sitatene er bearbeidet til sammenhengende tekst, og tydelige dialektkjennetegn er fjernet. Meningsinnholdet er noe kondensert, men muntlig stil er beholdt. Deltakerne har lest og godkjent både kondensert tekst og tekstnære fortolkninger av datamaterialet fra intervjuene.

5 3. semester består av fire moduler. Modulene er ikke avsluttende, men henger sammen og bygger på hverandre. Mellom modul tre og modul fire er det en praksisperiode på sju uker. MUL-aktiviteten er plassert i modul fire, like etter praksis og mot slutten av 3. semester.
} 
og bytter på å undervise hverandre. Slik erfarer alle studentene både rollen som studentlærer og å bli undervist av studentlærere.

\section{Studentlærernes planlegging og forberedelser}

I løpet av praksisstudiene i tredje semester deler studentene anonymiserte pasienthistorier og erfaringer fra praksis. Dette foregår via universitetets sikre nettløsning. Første dag tilbake på campus etter praksis møtes studentene sammen med en lærer for å danne studentlærergrupper (tre-seks studenter). Studentene velger tema selv, men fysioterapeutlærer (universitetsansatt lærer) sikrer at det er variasjon i tema, og at alle har en studentlærergruppe å være i. Deretter fortsetter erfaringsdeling og refleksjon over praksis i studentlærergruppene. Dette er ifølge studentene interessante og inspirerende samtaler. Etter hvert konkretiserer studentlærergruppene sine tema og formulerer problemstillinger for undervisningen. Problemstillingene skal være relevante for læringsutbyttene for modul en til fire. Undervisningen skal svare på problemstillingene, vise hvordan kunnskap og ferdigheter fra læringsaktiviteter på campus før praksis er tatt i bruk av studentlærerne i praksis, og være teorifestet og begrunnet. Undervisningen skal knyttes til selvopplevde caser fra praksis og inneholde både teori og ferdighetstrening. For øvrig står studentene fritt til å velge pedagogisk framgangsmåte og innhold. Eksempler på problemstillinger: «Hvordan undersøke barn med cerebral parese?» "Hvordan kommunisere med pasienter uten talespråk?» «Oppfølging etter kneproteseoperasjoner?» «Hvorfor er tverrfaglig samarbeid viktig?» «Hvordan møte pasienter med urealistiske mål?» «Hvordan gjennomføre en systematisk skulderundersøkelse?» "Bassengtrening - hvorfor og hvordan?»

Deretter planlegger gruppene undervisning. Med utgangspunkt i egne læringserfaringer definerer studentlærerne hvilket undervisningsinnhold som trengs for å lære resten av kullet det samme som de selv har forstått og lært i egne praksisstudier, og planlegger gjennomføring. I denne forberedelsesperioden (to dager) arbeider studentlærerne med å knytte teori til egne praksiserfaringer. Studentlærerne diskuterer hva de teoretisk må jobbe videre med og fordype seg $\mathrm{i}$, fordeler oppgaver til selve undervisningen og øver på relevante praktiske ferdigheter. 
Fysioterapeutlærerne kan tilkalles ved behov. Hver gruppe skal ha besøk av lærer minst en gang, men som oftest er lærer innom gruppene to-tre ganger i løpet av forberedelsesfasen. Studentlærergruppene ønsker å diskutere egne tanker, ber om tips til teori og trenger bekreftelse på planen for undervisning. Noen ganger ønskes hjelp fra lærer til praktisk øving.

\section{Gjennomføring av medstudentundervisning}

Studentlærergruppene har tre timer til disposisjon til undervisning, og alle studentlærere i gruppen bidrar aktivt. Det er gode diskusjoner underveis, ofte andre former for diskusjoner enn i lærerstyrt undervisning. Vanligvis er det stort engasjement. Studentlærerne er ivrige etter å lære bort. En student (2013) sier det slik: «Det er så gøy når du får med folk og det blir diskusjoner. Når du ser at folk skjønner noe nytt. Når jeg får spørsmål jeg kan svare på. Det er kjempedeilig!!

Studentene som blir undervist, er interesserte og motiverte. Det ser ut til at medstudentenes kunnskaper trigger lysten til å lære sjøl. Fysioterapeutlæreren er til stede mens studentene underviser hverandre. Hun støtter studentlærerne hvis de får spørsmål som er vanskelige å svare på, og rydder opp i eventuelle usikkerheter og uklarheter.

Tilstedeværelse i forberedelse og gjennomføring av undervisningen er obligatorisk, og studentlærerne får tilbakemelding fra lærer og medstudenter, men det er ikke noen formell godkjenning knyttet til kvaliteten på undervisningen. Dette synes ikke å ha negativ betydning for studentenes planlegging og gjennomføring av læringsaktiviteten. De aller fleste studentene legger mye arbeid i forberedelser, gjennomføring og deltakelse.

\section{Medstudentundervisning og -læring (MUL) - et teoretisk blikk}

Innenfor epistemologi har emosjoner tradisjonelt hatt lite fokus, og de har mest vært sett på som å være til hinder for kognisjon og fornuft (Brun, Doguoglu, Doguoglu, Brewer, \& Cohen, 2016, s. 1). Egne hverdagserfaringer viser oss likevel at epistemisk aktivitet er emosjonelt ladet. Emosjoner 
som nysgjerrighet, tvil, håp, frustrasjon, overraskelse og glede driver fram både kognitiv hverdagsaktivitet og akademisk forskning. Her utdyper jeg MUL i relasjon til teorier om situert læring, aktiv læring og dybdelæring og trekker inn emosjonenes betydning for læring.

\section{Situert læring}

Situert læringsteori er et godt egnet teoretisk fundament for læringsaktiviteter som tar utgangspunkt i studentenes erfaringer fra praksisstudiene. I situert læringsteori sees læring i lys av deltakelse i sosiale situasjoner, og kunnskap forstås som konstruert som følge av interaksjoner mellom deltakere i et praksisfellesskap $^{6}$ (Lave \& Wenger, 1991, s. 32-34). Læring sees med andre ord på som en aktivitet som foregår mellom mennesker i reelle situasjoner, og ikke som noe som foregår kontekstløst i hodene på enkeltpersoner. For studenter er praksissituasjoner fulle av reelle interaksjoner i sosiale situasjoner, med læring som mål. Studentene forteller om stressende praksisperioder, med mange nye krav og forventninger om prestasjon. Medstudentlæring var på mange måter en annerledes opplevelse, på tross av mye jobb: «Når du har hatt det presset i praksis over så lang tid og kommer tilbake til skolen, så kan man sitte rundt bordet og fortelle og diskutere og puste ut litt» (Student 2013). Fortellingene er fulle av emosjoner. Deling av vanskelige, morsomme, utfordrende og forvirrende historier bygger både tillit og selvtillit, og studentene modellerer både utilstrekkelighet og kompetent handling for hverandre.

Situert læringsteori fokuserte opprinnelig på de kognitive og kontekstuelle dimensjonene av læringen, og ikke på emosjonelle dimensjoner. Dette kan se ut til å være i endring (Fenton-O Creevy, Dimitriadis, \& Scobie, 2014; Turnbull, 2000; Wenger-Trayner \& Wenger-Trayner, 2015; Ytreberg \& Aars, 2015). Sharon Turnbull (2000, s. 3) mener at det ikke finnes distinksjoner mellom spørsmål om kunnskap og spørsmål om emosjoner innenfor et praksisfellesskap. Kognisjon er alltid både situert og emosjonelt ladet, og sosiale situasjoner i praksisfellesskaper vekker emosjoner, som på sin side bidrar til kognisjon og kunnskapsutvikling (Ytreberg \& Aars, 2015, s. 16).

\footnotetext{
Praksisfellesskap: Communities of practice. En spontan eller organisert gruppe som deler f.eks. interesse, oppgave, håndverk eller profesjon. Gruppa lærer av hverandre gjennom kunnskaps- og erfaringsdeling (Lave \& Wenger 1991, s. 98).
} 
Studenter er deltakere i flere praksisfellesskaper. Primært er de deltakere i praksisfellesskapet på utdanningen og i sitt eget kull; som student sammen med sine medstudenter. Dessuten har studentene hver for seg deltatt i ulike praksisfellesskaper på sine respektive praksisplasser. MUL med studentenes egne praksiserfaringer som utgangspunkt gir hver enkelt student muligheter for innsikt i medstudentenes praksisfellesskaper: «Du får liksom de andres praksiserfaringer, og da får du på en måte deres knagger å henge ting på. Veldig lærerikt!» (Student 2012).

Universitetslærere bruker også egne praksiserfaringer, men disse oppleves nok både mindre aktuelle og mindre virkelige for studentene enn medstudenters praksiserfaringer:

Det gikk igjen at folk brukte egne erfaringer når de forklarte. $\mathrm{Og}$ man linket hele tiden til noe i praksis. Det her har faktisk skjedd! Og det er noe noen har opplevd og erfart. Da blir det liksom virkelighet. Det er der ute (Student 2012).

Gjennom MUL får studentene tilgang til flere knagger enn hver enkelt har fått tilgang til fra egen praksis. På grunn av studentenes nære identifikasjon med hverandre kan innsyn i medstudenters praksisfellesskaper sees på som legitim perifer deltakelse ${ }^{7}$ by proxy, og det gir derfor legitim perifer deltakelse i variasjoner av praksisfellesskaper:

Folk hadde gjort forskjellige ting i praksis. ... Men vi kom jo fram til - gjennom prosessen - hvordan vi ville gjøre det og hva som var mest riktig. Vi fant litteratur og valgte ut og sånn. Men det var mye diskusjoner (Student 2013).

Variasjon er et viktig element i læring (Marton, 2018, s. 60). Ference Marton mener at for å kunne forstå en situasjon må vi forstå situasjonens kritiske elementer; eller situasjonens karaktertrekk. For å forstå situasjonens karaktertrekk må vi ha erfart variasjoner av samme situasjon, slik at vi skaper oss bilder av hva som varierer, og hva som er konstant. Læring skjer når man ser samme ting fra ulike perspektiver og ulike ting fra samme perspektiv

Sosialantropolog Jean Lave og pedagog Etienne Wenger introduserte begrepet «legitimate peripheral participation»: En nykommer i et praksisfellesskap blir gjennom deltakelse i enkle, men nødvendige og betydningsfulle oppgaver for praksisfellesskapet, etter hvert kjent med og inkludert i praksisfellesskapet (Lave \& Wenger 1991, s. 34-37). «... by proxy» er min egen tilføyelse. 
(Marton, 2018, s. 60). Det tar tid for studenter å erfare tilstrekkelige variasjoner over samme tema. Legitim deltakelse by proxy i variasjoner av praksisfellesskaper kan gi studenter muligheter til å se lignende praksiserfaringer fra flere perspektiver og ulike praksiserfaringer fra samme perspektiv, og slik konstruere egen kunnskap raskere og bredere enn om studentene skulle gjøre alle erfaringene direkte selv.

En profesjons kunnskapsbase er et "praksislandskap» bestående av et komplekst system av praksisfellesskaper og av grensene mellom disse praksisfellesskapene. Praksisfellesskap med en viss dybde forutsetter felles sosial læring innad i det aktuelle praksisfellesskapet. Det medfører dermed uunngåelige grenser mellom de som deler denne felles læringen, og de som ikke gjør det (Wenger-Trayner \& Wenger-Trayner, 2015, s. 17-19). Det kan være fristende å late som om det studenter lærer på campus, og det studenter lærer i praksis, helt uproblematisk kan overføres til hverandre, men slik er det ikke. Det er viktig å utvikle læringssituasjoner der campusverdenen og praksisverdenen kan møtes. Praksisfellesskapet som student på campus, praksisfellesskapet i praksisstudiene og de potensielt framtidige praksisfellesskapene man deltar i som ferdig utdannet fysioterapeut, bør ha tydelige forbindelseslinjer med hverandre. Erfaringsdeling og kunnskapsdeling i MUL trekker opp slike forbindelseslinjer.

\section{Kompetent identitet}

Læring innebærer ikke bare utvikling av ferdigheter og kompetanse, men også utvikling av identitet. Som profesjonell yrkesutøver skal man ikke bare lære «å gjøre», man skal også lære «å være». «Å være» i relasjon til andre innenfor et praksisfellesskap vekker alltid emosjoner (Fenton-O Creevy et al., 2014, s. 41). Identitet er heller ikke noe vi er eller har, uavhengig av sosial kontekst. I hvert nytt praksisfellesskap, og i ulike stadier og opplevelser av kompetanse, forhandles det om identitet (Fenton-O`Creevy et al., 2014, s. 33). En person som opplever seg som høyst kompetent i ett praksisfellesskap, kan erfare seg som nybegynner i et annet. I nye situasjoner og nye praksisfellesskap utsettes man for opplevelser av utilstrekkelighet og situasjoner der man ikke behersker det som kreves. Dette truer identiteten som kompetent person. Trussel mot egen identitet har sterke emosjonelle elementer. Man kan for eksempel føle seg utrygg, skamfull og liten (Fenton-O 'Creevy et al., 2014, s. 37). Som 
respons på truet identitet kan man ta i bruk ulike strategier. Man kan for eksempel trekke seg tilbake og forsøke å gjøre seg usynlig, eller beskytte seg selv med aggressivitet. Alternativet er å våge å stå i de ubehagelige følelsene, engasjere seg positivt så godt man kan, og redefinere sin identitet i det aktuelle praksisfellesskapet (Turner \& Stets, 2006, s. 30).

Praksisstudiene i tredje semester er fysioterapeutstudentenes første lange praksisperiode og en viktig introduksjon til framtidig yrkesliv som fysioterapeut. Inntakskravene på bachelorutdanningen i fysioterapi medfører at studentgruppen har høyt karaktergjennomsnitt og er vant til å levere gode skoleprestasjoner. Fysioterapeutstudenter flest har en identitet som kompetent skoleelev, gjerne en som er blant de flinke. Denne identiteten kan til en viss grad videreføres i første studieår, der hovedfokus er på tilegnelse av basiskunnskaper. På studiet møter man andre minst like kompetente studenter. Det kan i seg selv virke forstyrrende på egen identitet, men som oftest utfordres identiteten på alvor først i praksisstudiene. Der møter studentene sitt framtidige yrkesliv, nye utfordringer, og de evalueres på andre områder enn de har vært vant til fra tidligere. Slik beskriver en student møtet med sin praksisveileder: "Jeg følte det som et stort press, og at han vurderte meg ut fra hvordan han gjør ting» (Student 2013).

Det betyr at praksisstudiene oppleves som veldig viktige, men samtidig potensielt identitetstruende. Fysioterapeutstudenter forteller at de føler seg usikre og har dårlig selvtillit ved starten av praksisperiodene (Ytreberg \& Aars, 2015, s. 15). Ordet nervepirrende blir ofte brukt for å beskrive erfaringer fra praksis. Til en viss grad er nok usikkerhet en del av det å være student og møte nye og ukjente situasjoner og krav. Samtidig er det viktig for læring at studentene gradvis bygger identitet som kompetent fysioterapeutstudent. Dette er sentralt for etter hvert å erfare seg som kompetente profesjonsutøvere (Christie, Tett, Cree, Hounsell \& McCune, 2008). Det betyr at usikkerheten må håndteres og gradvis overvinnes:

Jeg husker jeg sa noe til en pasient på en litt klein måte i anamnesen. Etterpå begynte vi begge å le fordi vi begge (veileder og student) skjønte det var dumt. Og så snakka vi om det, og så fikk jeg en ny pasient der jeg kunne gjøre om på det jeg sa. Rette meg opp igjen! Det lærte jeg mye av. Å finne en måte å gjøre det bedre på, ikke bare reflektere (Student 2013). 
I løpet av praksisperioden i tredje semester bygges gradvis mestringsfølelse, knyttet til praksiskonteksten. Det er grunn til å tro at læringsaktiviteter som gir studenter emosjonelle opplevelser av mestring, vil fremme utvikling av kompetent fysioterapeutstudentidentitet innenfor de aktuelle praksisfellesskapene. Når studentene bruker sine praksiserfaringer til å undervise andre studenter, festes identiteten som kompetent student og profesjonsutøver i møte med undervisningsoppgaven og de andre studentene. En av studentene i vår studie sier det slik:

Jeg opplevde en sånn 'drive' mot å dele kunnskapen. Du ønsker å prestere ditt beste fordi du virkelig ønsker at de andre skal forstå. Det er en god følelse og veldig inspirerende å dele kunnskap om noe du kan godt selv! Man ser liksom at ... oi, det her! Får den gøttsen! Av at nå har man lært det videre liksom! (Student 2013).

Opplevelsen av å forstå noe vanskelig, være i stand til å forklare kompliserte, faglige tema og guide medstudenters læringsprosess viser seg å være høyst tilfredsstillende. Det er grunn til å tro at dette styrker selvtillit og kompetent identitet hos studentene (Mega, Ronconi \& De Beni, 2014; Topping, 2007; Ytreberg \& Aars, 2015).

\section{Praksisfellesskaper og læringsmiljø}

Utvikling av en trygg lærende identitet er tett sammenvevet med emosjonelle dimensjoner i læring (Mega et al., 2014), og trygg lærende identitet er avhengig av et trygt læringsmiljø. Turnbull (2000) viser at suksess i praksisfellesskaper henger sammen med grad av emosjonell støtte, nærhet og solidaritet innad i praksisfellesskapet. Når studenter har ansvar for å undervise hverandre, må de i løpet av prosessen akseptere og håndtere negative emosjoner, som usikkerhet og følelsen av å være på vei og ennå ikke vite nok. I et støttende og positivt læringsmiljø er det likevel mulig å føle seg trygg og modig nok til å bevege seg ut på ganske tynn is, for deretter erfare å komme trygt $\mathrm{i}$ land på den andre siden.

Studentene understreker betydningen av et støttende og positivt læringsmiljø i kullet og i gruppene. Når læringsmiljøet er trygt, blir studentene modigere, våger å vise hva de ennå ikke kan, og tør å dele feil: 
Jeg tenker at læringsmiljøet eller læringsklimaet er ganske sentralt. For at man tør å vise sine svakheter og utfolde seg. Og diskutere (...) at det ikke er sånn - hevde seg. Men læring! Og du lærer av å gjøre feil, og du lærer av å ikke kunne så mye. ... av å sette deg i de situasjonene (Student 2013).

Studentene viser også mot til å dele utfordrende og krevende erfaringer med hverandre, og de setter pris på at andre deler: «Den ene (veldig vanskelige) situasjonen der ... det blir jeg aldri til å glemme! (...) Bare at han var så åpen og delte sine tanker og følelser og reaksjoner og alt ... med oss! Det gjorde at jeg lærte kjempemye» (Student 2013).

Bevegelser mellom praksisfellesskaper er emosjonelt utfordrende, men gir også viktige muligheter for utvikling. Å erfare at egen kompetanse kan komme til nytte for medstudenters læring, synliggjør egen faglig vekst. Dette ser ut til å ha betydning i utvikling av en trygg, profesjonell identitet: «Det (kunnskapen) blir på en måte litt konstant. At du føler at nå kan man noe» (Student 2012). Slik kan erfaringer fra MUL bidra i konstruksjonen av en kompetent studentidentitet, og etter hvert til utvikling av en trygg og kompetent profesjonsidentitet.

\section{Dybdelæring}

Læring kan grovt sett deles i to: overfladisk læring og dybdelæring. Overfladisk læring kjennetegnes av hukommelse, pugg og nøyaktig gjengivelse av fragmenter, mens dybdelæring kjennetegnes av mønstergjenkjenning, forståelse og helhetstenkning (Marton, Entwistle \& Hounsell, 1984, s. 71-89). I fysioterapeututdanningen ønsker vi at studenter i størst mulig grad engasjerer seg i læring slik som Noel Entwistle (2009, s. 36) karakteriserer dybdelæring: Koble sammen kunnskaper fra flere felt, sammenligne, se etter mønster og underliggende prinsipper, være kritisk, bruke faktakunnskap der det er relevant, søke forståelse og ha oppmerksomhet mot utvikling av egen forståelse, være interessert og oppleve læring som meningsfullt i seg selv.

Studenter er disponert for enten overfladisk eller dyp læringsstil, men alle kan aktivere begge stiler, avhengig av hvilke forventninger og oppgaver de møter (Marton et al., 1984, s. 71-89). Studenter flest velger strategisk 
mellom læringsstiler, ofte med aller størst oppmerksomhet mot det som kreves av dem i kommende eksamener (Entwistle, 2001, s. 108). Studenters tilnærming til læring og læringsstil kan sees på som resultat av interaksjoner mellom studentens disposisjon, læringsmål, læringsaktivitet/-oppgaver og vurderingsform (Biggs \& Tang, 2011, s. 16-33).

\section{Aktiv læring}

Forelesningsformen forutsetter at studenter lærer ved å lytte, notere og lese selv, og egner seg godt til overfladisk læring. Aktiv læring framsettes gjerne som et alternativ til tradisjonelle forelesninger, og som en læringsmåte som fremmer dybdelæring. Aktiv læring kan foregå på mange måter, men involverer alltid aksjon (aktiv handling) og refleksjon. Charles Bonwell og James Eison (1991) lister opp følgende karakteristika for aktiv læring. Det femte punktet er seinere lagt til av Kayo Matsushita (2018):

- Studenter er involvert i mer enn å lytte; som å lese, diskutere og skrive

- Utvikling av studentens ferdigheter vektlegges mer enn informasjonsoverføring.

- Studenten engasjeres i høyere-ordens tenking; analyse, syntese og evaluering.

- Studentens utforsking av sine egne holdninger og verdier vektlegges (Bonwell \& Eison 1991, s. 19).

- Studenten eksternaliserer kognitive prosesser i det aktive (Matsushita, 2018, s. 15).

Alle kjennetegn ved aktiv læring finnes igjen i alle faser av MUL: Studentene er aktive i praksisstudiene, deretter er de aktive gruppedeltakere, og til slutt er de studentlærere. Refleksjon over aksjon skjer i flere omganger. Dessuten skal undervisningen inneholde både teoristoff og handlinger i form av praktisk øving med tilhørende refleksjon, slik at studentene også er aktive i rollen som student. 


\section{Dyp, aktiv læring}

I undervisning basert på tradisjonelle forelesninger kommer eksternalisering av kunnskaper til syne i eksamensbesvarelser, gjerne i skriftlig form, og det er ofte mulig å bruke overfladisk læring og pugg til å «komme igjennom». I profesjonsutdanningene holder det ikke at studentenes kunnskaper internaliseres i den enkelte student. Kunnskapen skal også eksternaliseres; anvendes og bli synlig i ulike former for handling, og aktiv læring kjennetegnes nettopp av at eksternalisering av kunnskap plasseres i selve læringsaktiviteten (Matsushita, 2018, s. 22). MUL innebærer at kunnskap eksternaliseres i det aktive i flere omganger: først i den enkelte students praksis, så i gruppe sammen med andre med lignende erfaringer, og dernest $i$ undervisning av medstudenter.

I dyp, aktiv læring søker man å kombinere internalisering og eksternalisering. Da foregår internalisering og eksternalisering ikke som «først det ene og så det andre», men i sirkulære og sammenlenkede prosesser (Matsushita, 2018, s. 22). Utsagn fra en av studentene illustrerer denne sirkulære prosessen godt: «Jo mer du jobber med et stoff for å få det pedagogisk og forståelig for andre, jo mer forståelig blir det kanskje for deg selv også» (Student 2012).

Matsushita (2018, s. 23) understreker at synliggjøring av læringsprosessene i seg selv er et element i dyp, aktiv læring. Dette erfares og forstås gradvis av to av studentene (2012) som del av prosessen:

Jeg føler at i løpet av den prosessen, så skjønte jeg hva det sto på arket at vi skulle gjøre. Og hvorfor. Og hvor lærerikt det faktisk var ... $\AA$ få forståelse for det vi skal gjøre, ikke bare vite at vi skal gjøre det. Så ... det ligger mye i det dere sier, men vi må gjøre det og lære oss det før vi forstår det egentlig.

Studenter er vant til at det stilles krav til gjengivelse av kunnskaper, «effektiv jobbing», og de blir hele tiden stilt overfor nytt lærestoff. Å møte en læringsaktivitet med fokus på dyp, aktiv læring kan oppleves uvant og som unødvendig repetisjon i begynnelsen, men hensikten blir klarere for studentene underveis i arbeidet:

En del av det var jo at vi ikke skulle ta for oss noe helt nytt. Det var det mange som var fristet til. Nå har vi jo lært oss noe nytt og kult 
i praksis, og så får vi ikke vise det?! Da blir det jo repetisjon?! (...) Men det ble bearbeidet kunnskap. Som vi har tatt videre. Ja, videreutviklet kunnskap som vi har tatt med i praksis og tatt til et høyere nivå. Og så lært tilbake til de andre. Det blir på en måte repetisjon, men pluss at du legger på litt til (Student 2012).

\section{Meeting of minds}

For å utvikle dyp, personlig forståelse trenger studenter først input. Det kan være at læreren formidler sine faglige kunnskaper og sitt faglige utgangspunkt, eller at studenten leser pensum. Deretter er det sentralt at studenten får rom til å utvikle egne tanker og egen forståelse:

Vi ser det kanskje først når vi kommer i praksis, så får vi en case og så begynner vi å tenke at vi gjorde jo noe på skolen i forhold til dette problemet vi ser hos pasienten, og så kanskje vi klarer å bruke det. (...) Veileder har jo også noen forslag, og det bruker du jo også. Så du må tenke selv (Student 2012).

I MUL er det rikelig anledning til å diskutere hver enkelt students praksiserfaringer på nytt: «Det (MUL) er vel en av de situasjonene jeg har lært mest av. For der er folk engasjerte, de har sine egne erfaringer som man kan snakke ut fra. Det var mange ting jeg forsto bedre etter de diskusjonene» (Student 2012). Slike «meeting of minds» beskrives som å være viktige for å aktivere positive emosjoner hos studenter (Entwistle, Karagiannopoulou, \& Ólafsdótti, 2018, s. 6), som igjen stimulerer til faglig utforsking og er korrelert med gode akademiske prestasjoner (Ainley, 2008; Entwistle et al., 2018; Pekrun, Goetz, Frenzel, Barchfeld \& Perry, 2011). Negative emosjoner er korrelert til mindre gode prestasjoner (Ainley, 2008; Pekrun et al., 2011), men frykten for negative emosjoner kan også være en driver for dybdelæring:

Du skulle jo liksom lære de andre noe, så da er det litt flaut og ekkelt å stå der hvis du ikke er forberedt. Hvis du bare snakker svada så merker jo folk det med en gang. Og hopper av. (...) at øyne ser mot deg og ikke i mobilen eller holder på å sovne eller noe sånt. For det 
er ikke en morsom situasjon å stå der oppe da! Da er ikke jeg høy i hatten i alle fall! (Student 2013).

Medstudentlæring ser altså ut til å ha potensial til å bringe fram positive emosjoner som styrker dypt engasjement og studentenes opplevelse av mestring, mens de samtidig øver på å håndtere frykten for negative emosjoner på gode måter.

Universitetslærere informert av situert læringsteori har tradisjonelt vært mest opptatt av å knytte læringens sosiale elementer til det kognitive (Ratner, 2007, loc. 1187). Inspirert av medstudentlæring og andre studier om emosjoners innvirkning på læring mener jeg å kunne anbefale å inkludere emosjonelle dimensjoner tydeligere i planlegging og gjennomføring av både MUL og andre undervisnings- og læringsaktiviteter. Kanskje har vi mye å lære av studentlærernes tanker om planlegging av undervisning:

Først er det å finne noe som ikke er for kjedelig, men som samtidig er litt utfordrende. Å sette i gang en tankeprosess tror jeg vi tenkte mye på. Vi tenkte mye på at det skulle være artig og ikke den vanlige undervisningen. (...) At alle henger med og at det er litt spennende (Student 2013).

\section{Roller i endring}

Avslutningsvis ser jeg på hvordan lærerrollen og studentrollen kan beskrives og forstås med erfaringer fra medstudentundervisning og -læring (MUL).

\section{Læreren - stillasbygger og samarbeidspartner}

Fysioterapeutlæreren har viktige roller i planlegging og gjennomføring av MUL, men rollene er annerledes enn foreleser- og ekspertrollene. Læreren er i stedet pedagogisk tilrettelegger, fasilitator, samarbeidspartner og kvalitetssikrer. Læreren etablerer et "stillas» eller en "forskaling» ${ }^{8}$ for læringsaktiviteten, slik det

8 Inspirert av Lev Vygotskij introduserte Jerome Bruner begrepet «scaffolding» på slutten av 1950-tallet. Det oversettes som oftest til stillas på norsk. Jeg synes forskaling er mer beskrivende. Fysioterapeutlæreren setter opp et rammeverk (forskalingen) som studentlærerne fyller med innhold. 
er beskrevet i del 1, mens studentene har ansvar for å fylle innholdet: «Det ble større utfordring å sjøl dra tråder og sånne ting. Og så prøve å presentere det for en lærer. Men det at vi sjøl dro i gang prosessen var fint» (Student 2013).

I lærerstyrte forelesninger framstår læreren som den aktive og kompetente, mens studentene er mer eller mindre passive mottakere. Mottakerrollen kan forsterke følelsen av avmektighet og usikkerhet hos studenter. I MUL er studentene aktive og kompetente, mens læreren inntar en støttende rolle der bekreftelse, tillit og passe utfordring er viktige stikkord. I startfasen bekrefter læreren at temaet er relevant, og at overordnet plan for forberedelser er tilstrekkelig målrettet. Underveis viser fysioterapeutlæreren tillit til at studentene har kunnskaper, ferdigheter, og bekrefter veivalg som studentene foretar. Fysioterapeutlæreren kan også utfordre ved å bringe inn nye eller alternative ideer. Slik stimuleres studentene til å strekke seg inn i den proksimale utviklingssonen (Vygotsky, 1978 s. 84-91), noe som fasiliterer til ytterligere dybdelæring. Det er likevel viktig at undervisningen er forankret i studentenes egne erfaringer og egne forberedelser: «Det var veldig greit at lærerne var disponible ved behov. Vi trengte tid alene først, så fikk vi henne litt inn, og så var vi alene, og så litt inn igjen. Vi spurte henne og hun gikk igjennom opplegget og kom med innspill» (Student 2013).

Mot slutten av planleggingsperioden og i evalueringen etterpå trenger studentlærere og studenter bekreftelse på at nivået og kvaliteten på undervisningen er tilstrekkelig. Læreren har med andre ord en kvalitetssikrende og samlende rolle for hele prosessen: «Det må være lærer tilstede. Det har med at folk kommer eller ikke. Hvor sikker er man på å få hele kullet til å være på. Det stiller litt høyere krav» (Student 2013).

\section{Studentlærer og student - symmetriske roller med felles referansepunkter}

Deling av emosjonelt ladede situasjoner er viktig for å styrke nærhet, identifikasjon, støtte og solidaritet i studentkullet (Ytreberg \& Aars, 2015, s. 16). I studier der prestasjoner jevnlig bedømmes ved karakter, kan det oppstå stor grad av konkurranse. Medstudentundervisning ser ut til å kunne skape et læringsorientert samarbeidsklima som potensielt svekker konkurranseelementet studentene imellom. Samarbeidsklimaet viser seg blant annet ved at studentene tar stort ansvar for hverandres læring. De har hatt praksis på 
ulike praksissteder, fått tilgang til et spekter av erfaringer og vet godt at mange av medstudentene ikke har fått anledning til å gjøre seg de samme erfaringene som de selv har gjort: «Vi er ansvarlige for de andre, for medstudentenes læring. Det var sånn interesse for å dele det man har lært av kunnskap. Man vil jo at de andre også skal forstå det» (Student 2012).

Et element i ansvarsfølelsen er gleden over å ta del i hverandres læring. Studentene blir rett og slett stolte av hverandre og deltar i andres positive emosjoner:

Og så syns jeg det er gøy å se på andre studenter. ... når de virkelig har jobba med det her. Og kan det, og prøver å formidle det. Det blir veldig spennende. Det er morsomt å se folk man kjenner personlig ha jobbet med noe og legger det fram og er god! Det er liksom litt anna følelse ... fordi man kjenner dem ... bedre enn lærerne (Student 2013).

Studentene inntar lærerrollen med annen type kunnskap enn fysioterapeutlærere. Studentlæreren har inngående kunnskaper om hva medstudentene trenger for å lære. Innholdet i medstudentstyrt undervisning oppleves derfor svært relevant og har presis vanskelighetsgrad for optimal læring:

Læreren gikk veldig systematisk igjennom diagnose for diagnose (før praksis), og forklarte alt og sånn., men husker at vi tenkte etterpå ... at vi likevel ikke helt hadde tråden. (...) Kanskje studentene skjønner seg litt mer på oss? Hvordan vi vil ha en oppbygning for å skjønne? (Student 2012).

Studenter på samme kull har deltatt i akkurat den samme undervisningen og vet hva som er gjennomgått, lært og ikke minst forstått fra tidligere:

Vi har de samme referansepunktene. Ofte kan en lærer bruke prinsipper til å forklare som man bare sånn halvveis har forstått, mens medstudenten har en annen innfallsvinkel. Budskapet kommer lettere fram. Hele situasjonen blir forandret (Student 2013).

Relasjoner mellom lærere og studenter er i utgangspunktet en asymmetrisk relasjon, og diskusjoner mellom lærer og student kan gi studenter følelsen av 
å bli prøvd og testet selv om det ikke er lærerens intensjon: «Det er ikke så lett å stole på egne kunnskaper i en diskusjon overfor en lærer. Med lærere så kjennes det som en test, man inntar oftere en slags forsvarsposisjon» (Student 2013).

I MUL jevnes maktforholdene ut. Læringsaktiviteter og diskusjoner framstår som samarbeidssituasjoner og reelle arenaer for utvikling av forståelse:

Når man stiller spørsmål til en lærer er det jo fordi dere er lærere. Og da får du spørsmål tilbake som gjør at du må reflektere. Men hvis du stiller spørsmål til en medstudent, så kommer man fram til enighet i lag. To liksom (Student 2013).

Det er krevende for studenter å være kritiske og utfordre lærere. Det kan også være vanskelig å fortsette å spørre hvis man får et svar man ikke helt forstår. Når læreren er en medstudent, mykes rollene opp:

Det er mye lettere å være kritisk til hverandre. Hvis jeg spør en medstudent om noe og ikke helt tror på svaret, så spør jeg videre. Men hvis det er en lærer så sier jeg ... okei. Man fortsetter ikke diskusjonen med en lærer på samme måte. Du stoler mer på at læreren kan det enn om det er en student. Du stiller større krav til at studenten skal kunne forklare det ordentlig (Student 2013).

Det er vanskelig å vite sikkert om erfaringer fra en mer symmetrisk relasjon mellom lærer og student har betydning videre i studiet, men studentenes utsagn sannsynliggjør at MUL kan være et bidrag til å utvikle trygge og selvstendige studenter.

\section{Kompetanse og kapasitet - livslang læring og profesjonell utvikling}

Utvikling av forståelse er et sentralt kjennetegn på dybdelæring. Dyp forståelse utvikles gjennom repetert internalisering og eksternalisering (Matsushita, 2018, s. 29). I MUL erfarer studentene hvordan dybdekunnskap utvikles. Opplevelsen av å ha dyp kunnskap og dyp forståelse er tilfredsstillende for egen læring. Slik erfaring er nyttig å ta med seg videre i studiet, men også 
viktig for profesjonslivet etter studiene. Profesjonsutdanning skal ha studentenes umiddelbare læring i fokus, men samtidig se det lange perspektivet. Grant Wiggins og Jay McTighe sier det slik: «What do we want students to understand and be able to use several years from now, after they have forgotten the details?» (Wiggins \& McTighe, 2005, s. 342). Det betyr at utdanningene ikke bare skal utvikle studentenes kompetanse, men også bidra til å utvikle studentenes kapasitet til kontinuerlig utvikling, tilpasse seg endringer og generere ny kunnskap (Fraser \& Greenhalgh, 2001, s. 799). Slik utvikling er blant annet avhengig av mestringstro (Bandura, 1997). I løpet av læreprosessen i MUL skjer det en kognitiv og sosial bevegelse fra læreransvar, via delt ansvar til studenteierskap, slik Debra Meyer og Julianne Turner (2007, loc. 3244) beskriver. Eller med andre ord: Forskalingen kan fjernes, og studentene har gjennom egen innsats mestret og integrert hverandres proksimale utviklingssoner.

\section{Avslutning}

Kapittelet viser at studenter fra samme kull lærer av å undervise og bli undervist av hverandre, og elementene som inngår i medstudentundervisning og -læring stimulerer til dybdelæring. Deltakelse by proxy i andre studenters praksisfellesskaper gir tilgang til stor variasjon, noe som er et viktig element i læring. Kombinasjonen av undervisning og læring er emosjonelt ladet, og situert læringsteori kan med fordel utvides til å inkludere emosjonelle dimensjoner, sammen med kognitive og kontekstuelle dimensjoner. Medstudentundervisning og -læring innebærer at studenter og lærere må forstå sine roller annerledes. Det oppstår mer symmetriske relasjoner mellom alle aktørene (studentlærere, lærere og studenter), og dette gir muligheter for å erfare og forstå læring som samarbeidssituasjoner der felles forståelse utvikles. Studentene utvikler kompetent identitet gjennom å erfare å ha tilegnet seg betydningsfulle kunnskaper og mestre lærerrollen. Til sammen gir medstudentlæring og -undervisning et godt grunnlag for å gi studenter kapasitet for livslang utvikling og læring. Avslutningsvis får en av studentene oppsummere og forsterke læringens emosjonelle aspekter: «Jeg tenker at den situasjonen vi har nå kunne vi hatt flere av. For det har vært veldig artig!» (Student 2012). 


\section{Referanser}

Ainley, M. (2008). "Interest and learning: From attraction to absorbing interest". J.A. Athanasou (red.), Adult educational psychology, s. 155-180. Rotterdam: Sense. DOI: https://doi.org/10.1163/9789087905552_008

Bandura, A. (1997). Self-efficacy: The exercise of control. New York: Freeman.

Biggs, T. \& Tang, C. (2007). Teaching for quality learning in the university. What the student does. Maidenhead: Mac Graw Hill.

Bonwell, C. C. \& Eison, J. A. (1991). Active Learning: Creating Excitement in the Classroom. ASHE-ERIC Higher Education Report nr. 1. Washington: ERIC Clearinghouse on higher education.

Brun, G., Doguoglu, U., Doguoglu, D. U., Brewer, P. B. \& Cohen, P. S. (2016). Epistemology and Emotions. Abingdon, United Kingdom: Routledge. DOI: https://doi.org/10.4324/9781315580128

Christie, H., Tett, L., Cree, V.E., Hounsell, J., \& McCune, V. (2008). "A real rollercoster of confidence and emotions. Learning to be a university student". Studies in higher education, 33(5), s. 567-581.

DOI: https://doi.org/10.1080/03075070802373040

Entwistle, N. (2001). "Conceptions, styles and approaches within higher education: Analytic abstractions and everyday experience". I R.J. Sternberg, L.F. Zangh (red.) Perspectives on thinking, learning, and cognitive styles, s. 103-136. Mahwah, NJ: Lawrence Erlbaum. DOI: https://doi.org/10.4324/9781410605986

Entwistle, N. (2009). Teaching for understanding at university : Deep approaches and distinctive ways of thinking. Basingstoke: Palgrave.

Entwistle, N., Karagiannopoulou, E., \& Olafsdottir, A. (2018). "Research into student learning and university teaching: Contrasting perspectives and levels of focus". Review of Business and Legal Sciences / Revista de Ciências Empresariais e Jurídicas, (30), s. 047-067. DOI: https://doi.org/10.4324/9781315675404

Fenton-O 'Creevy, M., Dimitriadis, Y. og Scobie, G. (2014). "Failure and resilience at boundaries. The emotional process of identity work". I E. Wenger-Trayner, M. Fenton-O'Creevy, S. Hutchinson, C. Kubiak \& B. Wenger-Trayner (Red.) Learning in landscapes of practice, s. 33-42. London: Routledge.

DOI: https://doi.org/10.4324/9781315777122

Fraser, S. W. og Greenhalgh, T. (2001). "Coping with complexity: educating for capability”. BMJ, 323(7316), s. 799-803.

DOI: https://doi.org/10.1136/bmj.323.7316.799 
Lave, J. og Wenger, E. (1991). Situated learning: Legitimate peripheral participation. København: Reitzel.

Marton, F. (2018). “Towards a Pedagogical Theory of Learning”. I K. Matsushita (Red.) Deep Active Learning: Toward Greater Depth in University Education, s. 5977. Singapore: Springer Singapore.

DOI: https://doi.org/10.1007/978-981-10-5660-4_4

Marton, F., Entwistle, N., \& Hounsell, D. (Red.) (1984). The experience of learning. Edinburgh: Scottish Academic Press.

Matsushita, K. (2018). "An Invitation to Deep Active Learning". I K. Matsushita (Red.) Deep Active Learning: Toward Greater Depth in University Education, s. 15-33. Singapore: Springer Singapore.

DOI: https://doi.org/10.1007/978-981-10-5660-4_2

Mega, C., Ronconi, L., \& De Beni, R. (2014). "What makes a good student? How Emotions, Self-regulated Learning, and Motivation Contribute to Academic Learning". Journal of Educational Psychology, 106(1), s. 121-131.

DOI: https://doi.org/10.1037/a0033546

Meyer, D. K. og Turner, J. C. (2007). "Scaffolding Emotions in Classrooms". I

P.A. Schutz \& R. Pekrun (Red.) Emotion in Education, s. 243-258. San Diego: Elsevier.

Pekrun, R., Goetz, T., Frenzel, A. C., Barschfeld, P., \& Perry, R.P. (2011).

"Measuring emotions in students' learning and performance: The Achievement Emotions Questionaire (AEQ)". Contemporary Educational Psychology, 25, s. 92-104. DOI: https://doi.org/10.1016/j.cedpsych.2010.10.002

Ratner, C. (2007). "A Macro Cultural-Psychological Theory of Emotions". I P.A. Schutz \& R. Pekrun (Red.) Emotion in Education, s. 89-106. San Diego, CA: Elsevier.

Topping, K. (2007). “Trends in Peer Learning”. Educational Psychology: An International Journal of Experimental Educational Psychology, 25(6), s. 631-645. DOI: https://doi.org/10.1080/01443410500345172

Topping, K. \& Ehly, S. (2001). Peer Assisted Learning: A Framework for Consultation. Journal of Educational and Psychological Consultation, (12)2, s. 113-132. DOI: https://doi.org/10.1207/S1532768XJEPC1202_03

Turnbull, S. (2000). "The role of emotion in situated learning and communities of practice". I Working Knowledge Conference (Sydney) - 2000. Ukjent. N/A, s. 453462. 
Turner, J. H. \& Stets, J. E. (2006). "Sociological Theories of Human Emotions". Annual Review of Sociology, (32)1, s. 25-52.

DOI: https://doi.org/10.1146/annurev.soc.32.061604.123130

Vygotsky, L. S. (1978). Mind in society: The development of higher psychological processes. Cambridge, MA: Harvard University Press.

Wenger-Trayner, E. \& Wenger-Trayner, B. (2015). "Learning in a landscape of practice. A framework”. I E. Wenger-Trayner, M. Fenton-O 'Creevy, S. Hutchinson, C. Kubiak \& B. Wenger-Trayner (Red.) Learning in Landscapes of Pracice, s. 13-29. London: Routledge.

DOI: https://doi.org/10.4324/9781315777122

Wiggins, G. P. \& McTighe, J. (2005). Understanding by design (Expanded 2. ed). Alexandria, Virginia: Association for Supervision and Curriculum Development. Ytreberg, B. \& Aars, M. (2015). "Emotions in true peer teaching and learning: Physiotherapy students' experiences”. European Journal of Physiotherapy, (17)1, s. 9-18. DOI: https://doi.org/10.3109/21679169.2014.983443 